\title{
PHYSIOLOGICAL RESPONSES TO CADMIUM, NICKEL AND THEIR INTERACTION IN THE SEEDLINGS OF TWO MAIZE (ZEA MAYS L.) CULTIVARS
}

\author{
JÁN PAVLOVKIN ${ }^{1 *}$, TATIANA ARTIUSHENKO ${ }^{2}$, DMITRY SYSHCHYKOV ${ }^{2}$, RODERIK FIALA ${ }^{1}$, \\ VLADIMÍR REPKA ${ }^{1}$, MILADA ČIAMPOROVÁ ${ }^{1}$
}

${ }^{1}$ Institute of Botany, Slovak Academy of Sciences, Bratislava, Slovak Republic

${ }^{2}$ Kryvyi Rig Botanical Garden NAS of Ukraine, Ukraine

PAVLOVKIN, J. - ARTIUSHENKO, T. - SYSCHYKOV, D. - FIALA, R. - REPKA, V. - ČIAMPOROVÁ, M.: Physiological responses to cadmium, nickel and their interaction in the seedlings of two maize (Zea mays L.) cultivars. Agriculture (Pol’nohospodárstvo), vol. 62, 2016, no. 4, p. 127-137.

In the leaves of maize seedlings, cultivars Premia and Blitz, the relatively low $2 \mu \mathrm{mol} / \mathrm{L}$ concentration of cadmium $(\mathrm{Cd})$, nickel $(\mathrm{Ni})$, or both metals acting simultaneously $(\mathrm{Cd}+\mathrm{Ni})$ for $72 \mathrm{~h}$, induced a significant metal accumulation, decrease in total $\mathrm{K}^{+}$content, reduction of light-induced membrane electrical potential $\left(E_{\mathrm{M}}\right)$ repolarisation in mesophyll cells and changes of ascorbic acid (AsA), dehydroascorbic acid (DHA) and glutathione (GSH) content. Shoot growth and the values of resting $E_{\mathrm{M}}$ did not change significantly. Increased $\mathrm{K}^{+}$leakage, from the leaves, and lipid peroxidation accompanied by increase of TBA-reactive substances (TBARS) were found only in cv. Blitz exposed to Cd $+\mathrm{Ni}$. This indicates a capability of high leaf-cell anti-oxidant pool to ameliorate the toxic effects on plasma membrane of single ions in both cultivars, and of $\mathrm{Cd}+\mathrm{Ni}$ only in cv. Premia. The decreased total content of $\mathrm{K}^{+}$in leaves in all variants indicated repressing the $\mathrm{K}^{+}$uptake and/or distribution to the shoots. Under anoxia, the magnitude of the repolarisation obtained after switching on the light was smaller in Cd-treated cultivar Premia than in the controls, and this also occurred in Ni- and $\mathrm{Cd}+\mathrm{Ni}$-treated cultivar Blitz.

Key words: maize leaves, heavy metals $(\mathrm{Cd}, \mathrm{Ni})$, plasma membrane integrity, photoelectric response, antioxidants

Heavy metals (HMs) such as cadmium $(\mathrm{Cd})$ and nickel $(\mathrm{Ni})$ are naturally occurring in the earth's crust. Cd is a non-essential element that negatively affects plants (Tran \& Popova 2013) while Ni in low concentrations fulfils a variety of essential roles in plants as a constituent of several metallo-enzymes, such as urease (Ahmad \& Ashraf 2011). However, uptake of higher quantities of Ni may turn toxic to plants (Seregin \& Kozhevnikova 2008). Due to anthropogenic and industrial activities, high soil concentrations of $\mathrm{Cd}$ and $\mathrm{Ni}$ can occur simultaneously.
In agriculture, this may be caused by using sewage sludge, decayed and composted wastes to enhance soil fertility (Alegria et al. 1991; Chopra et al. 2009) or by industrial waste water irrigation (Sharma et al. 2007).

Various physiological processes are impaired by $\mathrm{Cd}^{2+}$ and by excess $\mathrm{Ni}^{2+}$ resulting not only in common but also in specific symptoms of metal toxicity. Briefly, the common toxic effects are primarily manifested as plant growth inhibition, morphological alterations, decrease in biomass production,

RNDr. Ján Pavlovkin, CSc. ("Corresponding author), Institute of Botany, Slovak Academy of Sciences, Dúbravská cesta 9 , SK-84523, Bratislava, Slovak Republic. E-mail: jan.pavlovkin@savba.sk

Mgr. Tatiana Artiushenko, CSc., Department of Plant Physiology and Soil Biology, Kryvyi Rig Botanical Garden NAS of Ukraine, Marshaka str. 50, UA-50089 Kryvyi Rig, Ukraine

Mgr. Dmitry Syschykov, CSc., Department of Plant Physiology and Soil Biology, Kryvyi Rig Botanical Garden NAS of Ukraine, Marshaka str. 50, UA-50089 Kryvyi Rig, Ukraine

Mgr. Roderik Fiala, PhD., Institute of Botany, Slovak Academy of Sciences, Dúbravská cesta 9, SK-84523, Bratislava, Slovak Republic

RNDr. Vladimír Repka, CSc., Institute of Botany, Slovak Academy of Sciences, Dúbravská cesta 9, SK-84523, Bratislava, Slovak Republic

RNDr. Milada Čiamporová, CSc., Institute of Botany, Slovak Academy of Sciences, Dúbravská cesta 9, SK-84523, Bratislava, Slovak Republic 
membrane distortion leading to decrease of essential mineral nutrients, changes in nitrogen metabolism, disturbance of water status, production of toxic metabolites and reactive oxygen species (ROS). These may react with lipids, proteins, pigments, and nucleic acids and initiate lipid peroxidation. Ultimately, all of these altered processes result in reduced yields of agricultural crops (Tran \& Popova 2013; Ahmad \& Ashraf 2011).

The plasma membrane (PM) of living cells represents the major barrier between cytoplasm and environment and is the first functional site of contact of the cells with any ion. In fact, PM contains potential Cd- and Ni-sensitive enzyme systems, such as PM $\mathrm{H}^{+}$ATPase (Ros et al. 1992). An increase in ermeability related to membrane damage was observed in plants subjected to Cd and Ni stress (Sanz et al. 2009; Fiala et al. 2015), resulting in disruption of membrane integrity and ionic homeostasis of cells. On the other hand, ROS generated by $\mathrm{Cd}$ and $\mathrm{Ni}$ are generally reported to increase lipid peroxidation in plants (Wu et al. 2003; Gajewska et al. 2012). However, as soon as any HM penetrates the cells, antioxidative endogenous defence mechanisms are stimulated that can remove, neutralise or scavenge oxygen radicals and their intermediates by antioxidant enzymes or non-protein thiol groups, especially GSH and AsA (Pandey et al. 2009).

The most common symptoms of $\mathrm{Cd}$ and Ni toxicity are structural and functional alterations in photosynthetic apparatus due to reduced uptake of essential elements (Maximović et al. 2007). Previous studies also showed that photosystem II (PSII) was extremely sensitive to $\mathrm{Cd}$ and $\mathrm{Ni}$, and its function was inhibited to a much greater extent than that of PSI (Ghasemi et al. 2012; Duan et al. 2010). It seems that there are no data available, concerning the action of $\mathrm{Cd}$ and $\mathrm{Ni}$ on $E_{\mathrm{M}}$ with regard to dark/ light signals in terrestrial plants. Some results on these parameters are known from the cells of maize leaves treated with lead (Pazurkiewicz-Kocot \& Pietruszka 2000) and of macroalga Nitellopsis treated with cadmium and lead (Kurtyka et al. 2011).

Most of our knowledge is based on the effects of $\mathrm{Cd}$ and $\mathrm{Ni}$ acting as individual ions on plethora of plant physiological processes. However, under natural environments, the plants must cope with combined action of several HMs. Differential re- sponses particularly due to metal ion interactions were shown after $\mathrm{Cd}, \mathrm{Ni}$ and their joint application in maize roots (Artiushenko et al. 2012) and in elodea leaves (Maleva et al. 2012) while no substantial interactions were found with regard to phytochelatins biosynthesis in tobacco cells (Nakazawa et al. 2001) or transport processes and transpiration in $\mathrm{Ni}$ hyperaccumulator Leptoplax emarginata (Bartoli et al. 2012).

The goal of this study was to extend our knowledge on the responses of leaf cell $E_{\mathrm{M}}$ and plasma membrane integrity, to relatively low $2 \mu \mathrm{mol} / \mathrm{L}$ concentration of $\mathrm{Cd}$ and $\mathrm{Ni}$ acting as single ions as well as both metals together, and the role of antioxidants AsA and GSH in stress response of two commercially available maize cultivars Premia and Blitz.

\section{MATERIAL AND METHODS}

\section{Plant material and growth conditions}

Two Ukrainian maize (Zea mays L.) cultivars Premia FAO 190 and Blitz FAO 160 available commercially (http://maize.com.ua/catalog) were used. The seeds were soaked in running water for $1 \mathrm{~h}$, surface sterilised with $5 \% \mathrm{NaClO}$ for $10 \mathrm{~min}$, washed for $10 \mathrm{~min}$ and germinated in moistened filter paper rolls at $25^{\circ} \mathrm{C}$ for $72 \mathrm{~h}$. The seedlings with the first leaf were exposed to aerated hydroponic treatments of distilled water (control), and $2 \mu \mathrm{mol} / \mathrm{L}$ concentrations of $\mathrm{Cd}^{2+}\left(3 \mathrm{CdSO}_{4} \times 8 \mathrm{H}_{2} \mathrm{O}\right)$ or $\mathrm{Ni}^{2+}\left(\mathrm{NiSO}_{4}\right.$ $\times 6 \mathrm{H}_{2} \mathrm{O}$ ) or to their combination for $72 \mathrm{~h}$ at laboratory conditions. Control and metal solution $\mathrm{pH}$ was adjusted to 5.7. The relatively low metal concentrations were selected as they reduced but not completely stopped the root growth (Artiushenko et al. 2012). To obtain dry matter values, the leaves of the control and treated plants were washed thoroughly, surface-dried with filter paper, dried at $70^{\circ} \mathrm{C}$ for $72 \mathrm{~h}$ and weighed.

\section{Determination of $\mathrm{Cd}$ and $\mathrm{Ni}$ contents}

The leaves of the seedlings were dried at $80^{\circ} \mathrm{C}$ and used for $\mathrm{Cd}$ and $\mathrm{Ni}$ contents determination according to Angelova et al. (2004). The HMs concentration was determined using atomic absorption spectrophotometer S-115U, SelmiOAO, (Ukraine) and related to the fresh weight (Borzou \& Azizinezhad 2012). 


\section{Electrophysiological measurements}

In the segments excised from the first leaf of the 72-h-treated seedlings, the $E_{\mathrm{M}}$ was measured using standard microelectrode technique (Pavlovkin et al. 1986). After rinsing the leaf segments with $0.5 \mathrm{mmol} / \mathrm{L} \mathrm{CaSO}_{4}$, they were mounted in $4 \mathrm{~mL}$ volume Plexiglas chamber and were constantly perfused $(10 \mathrm{~mL} / \mathrm{min})$ with a bathing solution containing $0.2 \mathrm{mmol} / \mathrm{L} \mathrm{KCl}, 1 \mathrm{mmol} / \mathrm{L} \mathrm{NaH}_{2} \mathrm{PO}_{4}, 0.2 \mathrm{mmol} / \mathrm{L}$ $\mathrm{Ca}\left(\mathrm{NO}_{3}\right)_{2}$ and $0.5 \mathrm{mmol} / \mathrm{L} \mathrm{MgSO}_{4}$ (control medium) adjusted to $\mathrm{pH} 5.7$ with $0.1 \mathrm{~mol} / \mathrm{L} \mathrm{HCl}$. The HM-containing bathing solutions consisted of the control medium supplemented with $2 \mu \mathrm{mol} / \mathrm{L}$ concentrations of $\mathrm{Cd}, \mathrm{Ni}$, or both metal ions together. The $E_{\mathrm{M}}$ was then measured using micropipettes filled with $3 \mathrm{~mol} / \mathrm{L} \mathrm{KCl}$. The tip diameter was $0.5 \mu \mathrm{m}$, tip potential -5 to $-15 \mathrm{mV}$. Micromanipulator was used to insert micropipettes into single leaf mesophyll cells under microscope control.

To register the photoelectric changes of $E_{\mathrm{M}}$, the leaf segments were illuminated with an light intensity of $120 \mu \mathrm{W} / \mathrm{cm}$ for $4 \mathrm{~h}$ and then the leaf cell responses to dark or light were continuously recorded for 30-60 min. All experiments were carried out at $22^{\circ} \mathrm{C}$. For $E_{\mathrm{M}}$ measurements in the dark, a green filter was placed in front of the light source during micropipette impalement of the cells.

\section{Potassium determination}

For potassium determination, the plants were cultivated in the solution without HMs (control) or supplemented with $2 \mu \mathrm{mol} / \mathrm{L}$ concentrations of $\mathrm{Cd}$, $\mathrm{Ni}$ and $\mathrm{Cd}+\mathrm{Ni}$ for $72 \mathrm{~h}$. The leaf segments $(1 \mathrm{~g})$ were rinsed briefly with $0.5 \mathrm{mmol} / \mathrm{L} \mathrm{CaSO}_{4}$, and the $\mathrm{K}^{+}$was extracted by boiling the tissue in distilled water for $10 \mathrm{~min}$. Alternatively, $\mathrm{K}^{+}$leakage was analysed from leaf segments treated for $72 \mathrm{~h}$ in the medium containing $\mathrm{HMs}$ at the concentration of $2 \mu \mathrm{mol} / \mathrm{L}$ and the contents of $\mathrm{K}^{+}$were measured in the leaf surrounding media. The $\mathrm{K}^{+}$concentrations in both cases were determined with an ion-meter CyberScan 2100 (Eutech Instr. PTE Ltd., Singapore) and were related to fresh weight.

\section{Content of thiobarbituric acid-reactive substances} (TBARS)

The content of TBARS was measured according to Hodges et al. (1999). The tissue homogenate prepared with $0.1 \mathrm{~mol} / \mathrm{L}$ potassium phosphate buffer containing $0.25 \mathrm{~mol} / \mathrm{L}$ sucrose was centrifuged at $8,000 \mathrm{~g}$ for $20 \mathrm{~min}$. To $0.5 \mathrm{~mL}$ of the supernatant $2 \mathrm{~mL}$ $\mathrm{H}_{2} \mathrm{O}, 1 \mathrm{~mL}$ of $17 \%$ trichloroacetic acid and $1 \mathrm{~mL}$ of $0.8 \%$ thiobarbituric acid were added. Then the mixture was heated in a boiling water bath for 20 min. Immediately after incubation, the mixture was cooled down in an ice bath. Absorbance at $532 \mathrm{~nm}$ wavelength was read in the supernatant against a blank.

\section{Extraction and analysis of AsA and DHA}

Leaves $(1 \mathrm{~g})$ were homogenised in $5 \%$ metaphosphoric acid at $4{ }^{\circ} \mathrm{C}$. The homogenate was centrifuged at $18,000 \mathrm{~g}$ and the supernatant was then used. The AsA and DHA contents were determined according to Kampfenkel et al. (1995) with modifications by de Pinto et al. (1999).

\section{Content of GSH}

The glutathione pool was assayed according to previously described methods of Beutler et al. (1963) modified by Gryshko and Syshchykov (2002) and the optical density was measured at $412 \mathrm{~nm}$ using spectrophotometer SF-2000 UV/Vis (OKB Spectr, Russia).

\section{Statistical analysis}

Data were analysed using one-way ANOVA with $P<0.05$ or 0.01 (Prism 5, GraphPad Software Inc., USA). Means and standard deviations were calculated from three independent experiments ( $n=3-30$ leaf segments). Each experiment was repeated at least three times.

\section{RESULTS AND DISCUSSION}

\section{Dry matter accumulation}

Dry weight accumulation was slightly higher in the control and treated leaves of the cultivar Blitz than in Premia. However, there were not statistically significant differences between control and metal-treated seedlings (data not shown). In contrast to roots (Martinka, personal communication), the dry weight of the leaves was not significantly affected by metal treatments (Table 1). Likewise, unaffected dry mater accumulation was found also in the rice shoots exposed to Cd or Ni (Rubio et al. 1994). This might be explained by the lower metal concentra- 
tions in shoots compared to roots as has been reported for maize (Maksimović et al. 2007) and by higher level of antioxidants in leaves than in roots (Jozefczak et al. 2015), which can better protect the leaves from damage.

\section{Metal accumulation}

Both maize cultivars accumulated $\mathrm{Cd}$ and $\mathrm{Ni}$ in their leaves when the metals were present in the root medium during $72 \mathrm{~h}$ (Figure 1). As could be expected, $\mathrm{Cd}$ or Ni concentrations in the leaves corresponded with the presence of the individual metal in the root medium. Comparing the cultivars exposed to $\mathrm{Cd}$ or Ni alone as well as to both metals together, significantly greater amounts of the respective metals were accumulated in Premia than in Blitz. Within each cultivar, the exposure to combined $\mathrm{Cd}$ $+\mathrm{Ni}$ treatment lowered the accumulation of either $\mathrm{Cd}$ or $\mathrm{Ni}$ comparing to their concentrations when the respective metals were administered separately. This could indicate antagonistic relations manifested in decreasing the metal entry into the cells ow- ing to competition between $\mathrm{Cd}$ and $\mathrm{Ni}$ as suggested for maize roots (Jozefczak et al. 2015) and Elodea leaves (Maleva et al. 2012). The amounts of $\mathrm{Cd}$ and $\mathrm{Ni}$ accumulated in leaves were substantially lower than the concentrations detected in the roots of the same maize cultivars (Artiushenko et al. 2012). However, the tendencies of accumulating more $\mathrm{Ni}$ than $\mathrm{Cd}$ as well as the antagonistic relations were similar in both plant parts.

$E_{\mathrm{M}}$

$\mathrm{Cd}$ and Ni have been shown to inhibit photosynthesis, namely photosystem II activity and affect the structure and function of protoplasmic membranes (Maksimović et al. 2007; Duan et al. 2010; Ghasemi et al. 2012). However, most of the studies on the effects of HMs on photosynthesis have been carried out on isolated chloroplasts and little information is presently available on their effect on $E_{\mathrm{M}}$ and photoelectric reaction of leaf parenchyma cells. In this study, we, for the first time, report on the effects

$\mathrm{T}$ a b 1 e 1

Shoot dry weight of Premia and Blitz seedlings grown in the root media containing distilled water (Control), $2 \mu \mathrm{mol} / \mathrm{L} \mathrm{Cd}^{2+}, 2 \mu \mathrm{mol} / \mathrm{L} \mathrm{Ni}^{2+}$, or $2 \mu \mathrm{mol} / \mathrm{L} \mathrm{Cd}^{2+}+2 \mu \mathrm{mol} / \mathrm{L} \mathrm{Ni}^{2+}$ for $72 \mathrm{~h}$. (Mean weights in $\mathrm{mg} \pm \mathrm{SD}$; the same letters indicate no statistically significant differences at $P<0.05)$.

\begin{tabular}{|l|c|c|c|c|}
\hline \multirow{2}{*}{ Treatments } & \multicolumn{4}{|c|}{ Leaf dry weight $[\mathrm{mg}]$} \\
\cline { 2 - 5 } & Control & $\mathrm{Cd}$ & $\mathrm{Ni}$ & $\mathrm{Cd}+\mathrm{Ni}$ \\
\hline Premia & $16.92 \pm 1.923^{\mathrm{a}}$ & $17.31 \pm 1.846^{\mathrm{a}}$ & $15.58 \pm 1.154^{\mathrm{a}}$ & $15.19 \pm 1.923^{\mathrm{a}}$ \\
Blitz & $21.35 \pm 2.5^{\mathrm{b}}$ & $21.92 \pm 2.885^{\mathrm{b}}$ & $17.69 \pm 2.5^{\mathrm{ab}}$ & $21.54 \pm 2.673^{\mathrm{b}}$ \\
\hline
\end{tabular}

T a $\quad$ b 1 e e 2

Concentration of TBARS, increase of $\mathrm{K}^{+}$concentration in the surrounding medium leaked from the leaf segments, expressed as $\%$ of control (dash = no increase), and $\mathrm{K}^{+}$content in the leaf segments of maize seedlings, cv. Premia and cv. Blitz, control and treated with $2 \mu \mathrm{mol} / \mathrm{L} \mathrm{Cd}, 2 \mu \mathrm{mol} / \mathrm{L} \mathrm{Ni}$ and $2 \mu \mathrm{mol} / \mathrm{L} \mathrm{Cd}+$

$2 \mu \mathrm{mol} / \mathrm{L}$ Ni for $72 \mathrm{~h}$. Values are means $\pm \mathrm{SD}(\mathrm{n}=3){ }^{*}=$ values significantly different from control.

\begin{tabular}{|c|c|c|c|c|c|c|}
\hline \multirow{2}{*}{} & \multicolumn{2}{|c|}{$\begin{array}{c}\text { TBARS } \\
{[\mu \mathrm{M} \text { TBA mg-1 protein }]}\end{array}$} & $\begin{array}{c}\text { Increase of } \mathrm{K}^{+} \text {concentration } \\
{[\% \text { of control] }}\end{array}$ & \multicolumn{2}{c|}{$\begin{array}{c}\mathrm{K}^{+} \text {content } \\
{\left[\mu \mathrm{M} \mathrm{K}^{+} \mathrm{g}^{-1} \mathrm{FW}\right]}\end{array}$} \\
\cline { 2 - 7 } & Premia & Blitz & Premia & Blitz & Premia & Blitz \\
\hline Control & $2.52 \pm 0.341$ & $2.23 \pm 0.096$ & - & - & $28.2 \pm 3.1$ & $26.1 \pm 3.2$ \\
$\mathrm{Cd}$ & $2.60 \pm 0.126$ & $2.48 \pm 0.153$ & - & - & $20.8 \pm 2.9^{*}$ & $21.5 \pm 2.6^{*}$ \\
$\mathrm{Ni}$ & $2.07 \pm 0.154$ & $1.89 \pm 0.161$ & - & $1.2 \pm 1.1$ & $22.7 \pm 2.2^{*}$ & $20.2 \pm 2.5^{*}$ \\
$\mathrm{Cd}+\mathrm{Ni}$ & $2.70 \pm 0.282$ & $2.50 \pm 0.05^{*}$ & - & $9.7 \pm 3.1^{*}$ & $23.9 \pm 2.6^{*}$ & $23.1 \pm 2.4^{*}$ \\
\hline
\end{tabular}




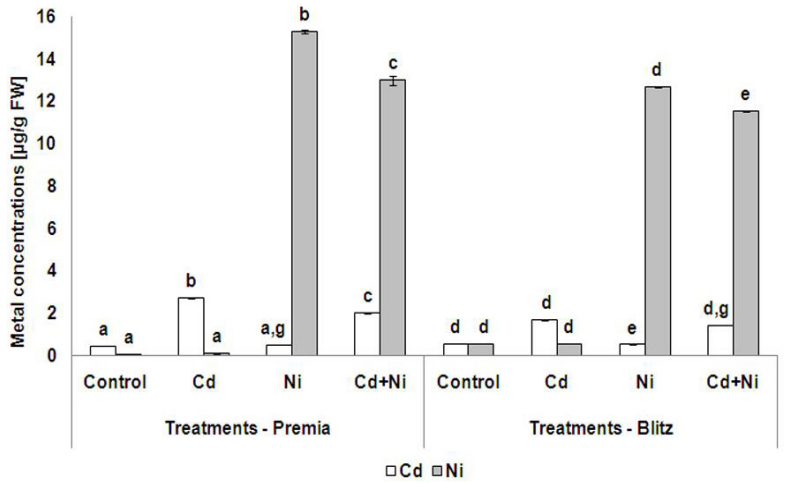

Figure 1. Accumulation of $\mathrm{Cd}$ and $\mathrm{Ni}$ in the shoots of Premia and Blitz seedlings grown in the root media containing $2 \mu \mathrm{mol} / \mathrm{L} \mathrm{Cd}^{2+}, 2 \mu \mathrm{mol} / \mathrm{L} \mathrm{Ni}^{2+}$, or $2 \mu \mathrm{mol} / \mathrm{L}$ $\mathrm{Cd}^{2+}+2 \mu \mathrm{mol} / \mathrm{L} \mathrm{Ni}^{2+}$ for $72 \mathrm{~h}$. (Mean amounts in $\mu \mathrm{g} / \mathrm{g}$ fresh weight with bars representing standard deviations; the same letters indicate no statistically significant differences at $P<0.05$ ).

of $\mathrm{Cd}$, $\mathrm{Ni}$ and $\mathrm{Cd}+\mathrm{Ni}$ on photoelectric reaction in maize leaf mesophyll cells.

Generally, the dark/light signals cause an electrical reaction in plant cells, depending on plant species, cell type and physiological status of the cells (Ullrich-Eberius et al. 1983; Shabala \& Newman 1999; Pazurkiewicz \& Pietruszka 2000). In maize leaf segments of 6-day-old seedlings, control and treated with HMs for $72 \mathrm{~h}$, the $E_{\mathrm{M}}$ values in mesophyll cells under light and dark conditions were $-174 \pm 7.1 \mathrm{mV}(n=20)$ in Premia and $-173 \pm 7.1 \mathrm{mV}$ $(n=16)$ in Blitz. Upon switching the light off (D) and on (L) in control seedlings, only transient depolarisation and hyperpolarisation, respectively, occurred in the leaves (Figure 2, control trace), similarly as in the leaves of majority of higher plant species (Pavlovkin et al. 1986). In the seedlings undergoing HM treatments for $72 \mathrm{~h}$, the pattern and velocity of $E_{\mathrm{M}}$ changes upon switching the light off (D) and on (L) showed differences, depending on both metal and maize cultivar (Figure 2). The treatment with $\mathrm{Cd}$ enhanced the dark-induced $E_{\mathrm{M}}$ depolarisation, the magnitude of which was double of that in control leaf cells in both cultivars. After switching the light on, namely within the first $30 \mathrm{~min}$, the pattern of $E_{\mathrm{M}}$ was altered in both cultivars. The phase of hyperpolarisation of $E_{\mathrm{M}}$ in Premia was much more reduced in comparison to control and Blitz. Comparing to control, Ni had no effect on either pattern or magnitude of $E_{\mathrm{M}}$ changes in Premia while in Ni-treated cv.
Blitz, the magnitude of dark-induced depolarisation enlarged two-fold and, after switching the light on, the $E_{\mathrm{M}}$ increased only slightly (Figure 2, Ni). The dark-induced depolarisations were greater after $\mathrm{Cd}$ $+\mathrm{Ni}$ treatment in comparison to single $\mathrm{Cd}$ or $\mathrm{Ni}$ in both cultivars and, the change was more conspicuous in Blitz in comparison to Premia (Figure 2, Cd $+\mathrm{Ni}$ ). However, in plants treated by $\mathrm{Cd}+\mathrm{Ni}$, the $E_{\mathrm{M}}$ values after repolarisation, in any case, did not reach the $E_{\mathrm{M}}$ values recorded after repolarisation in plants treated with single metals (Figure 2). This clearly indicated a synergic effect of the metals on plasma membrane responses. The combined $\mathrm{Cd}+\mathrm{Ni}$ treatment enhanced the dark-induced $E_{\mathrm{M}}$ depolarisation 2.5 times compared to control in both cultivars and the repolarisation was reduced particularly in Blitz. Switching the light on only weakly increased the $E_{\mathrm{M}}$ within 30-60 min (Figure 2, Cd +Ni). However, it is important to mention that following further $6 \mathrm{~h}$, the $E_{\mathrm{M}}$ values recorded either in the dark or in the light returned to the control values (data not shown). This $E_{\mathrm{M}}$ recovery in light probably resulted in compensation of ATP source for $\mathrm{H}^{+}$-ATPase from oxidative phosphorylation, rather than from photophosporylation. However, considering single metal effects on the repolarisation, $\mathrm{Cd}$ was more effective in Premia and $\mathrm{Ni}$ in Blitz.

To determine which energy sources contributed to the maintenance of $E_{\mathrm{M}}$ in maize leaf mesophyll cells in the light, i.e. mitochondrial phosphorylation, or photophosphorylation, we applied anoxia $\left(\mathrm{N}_{2}\right)$ in another set of experiments. Perfusion with $\mathrm{N}_{2}$-saturated solution alone in the light caused transient membrane depolarisation of a few millivolts $(3.1 \pm 1.1 \mathrm{mV}, n=7$, mean $\pm \mathrm{SD})$ in control and HM-treated cells (data not shown). $\mathrm{N}_{2}$ in the dark depolarised the $E_{\mathrm{M}}$ to the values between -62 and $-73 \mathrm{mV}(-69 \pm 4.9 \mathrm{mV}, \mathrm{n}=13$, mean $\pm \mathrm{SD})$ in both cultivars in control as well as HM-treated cells (due to inhibition of oxidative phosphorylation). After depolarisation by $\mathrm{N}_{2}$ in the dark, the $E_{\mathrm{M}}$ in control cells of both cultivars recovered completely within 15-20 min following the change from $\mathrm{N}_{2} /$ dark to $\mathrm{N}_{2} /$ light (Figure 3, control trace) (as a result of energy supply from photophosphorylation). Similar velocity was recorded also upon switching from $\mathrm{N}_{2}$ to air in both control and HM-treated plants (indicating the energy supply from oxidative phosphorylation). 
The $E_{\mathrm{M}}$ recovered completely within 15-30 min in both cultivars (data not shown).

In HM-treated plants, under $\mathrm{N}_{2}$ /light, the $E_{\mathrm{M}}$ repolarised similarly but not as completely as in control, within the first $30 \mathrm{~min}$, in dependence of metal treatment and cultivar (Figure 3). Following $30 \mathrm{~min}$, the magnitude of $E_{\mathrm{M}}$ repolarisation was the highest in Ni-treated, lower in $\mathrm{Cd}$ - and $\mathrm{Cd}+\mathrm{Ni}$-treated Premia. In the leaf cells of Blitz, the magnitude of repolarisation was similar after $\mathrm{Cd}$ or $\mathrm{Ni}$ treatments and the lowest after $\mathrm{Cd}+\mathrm{Ni}$ treatment. Comparing the cultivars, Premia seems to be more sensitive to $\mathrm{Cd}$, and Blitz to Ni. After 180 min under $\mathrm{N}_{2}$ /light, the values of $E_{\mathrm{M}}$ repolarisation were not statistically different from those in control regardless of the HM treatment (data not shown).

Taken together, the inhibition of membrane repolarisation in maize leaf cells treated with $\mathrm{Cd}, \mathrm{Ni}$ or both together, cannot be considered as the more serious HM stress symptoms under sustained depression of the driving force energising PM-ATPase (Kurtyka et al. 2011) because the $E_{\mathrm{M}}$ repolarised spontaneously after $3 \mathrm{~h}$ following switching on the $\mathrm{N}_{2}$ /light, and $\mathrm{N}_{2}$ /air conditions.

These results could be interpreted by assuming that HMs only transiently inhibited photophosphorylation but had no effect on oxidative phosphorylation in maize leaf cells. We suggest that the inhibition of repolarisation was due to an effect of metals on PS II system (Duan et al. 2010), as a result of a short-term insufficient ATP synthesis needed for standard activity of plasma membrane $\mathrm{H}^{+}$-ATPase, which maintains the $E_{\mathrm{M}}$ (Ullrich-Eberius et al. 1983).

\section{TBARS content, $K^{+}$efflux and $K^{+}$content}

Another symptom of membrane damage induced by $\mathrm{Cd}$ and $\mathrm{Ni}$ is an increase in membrane perme-
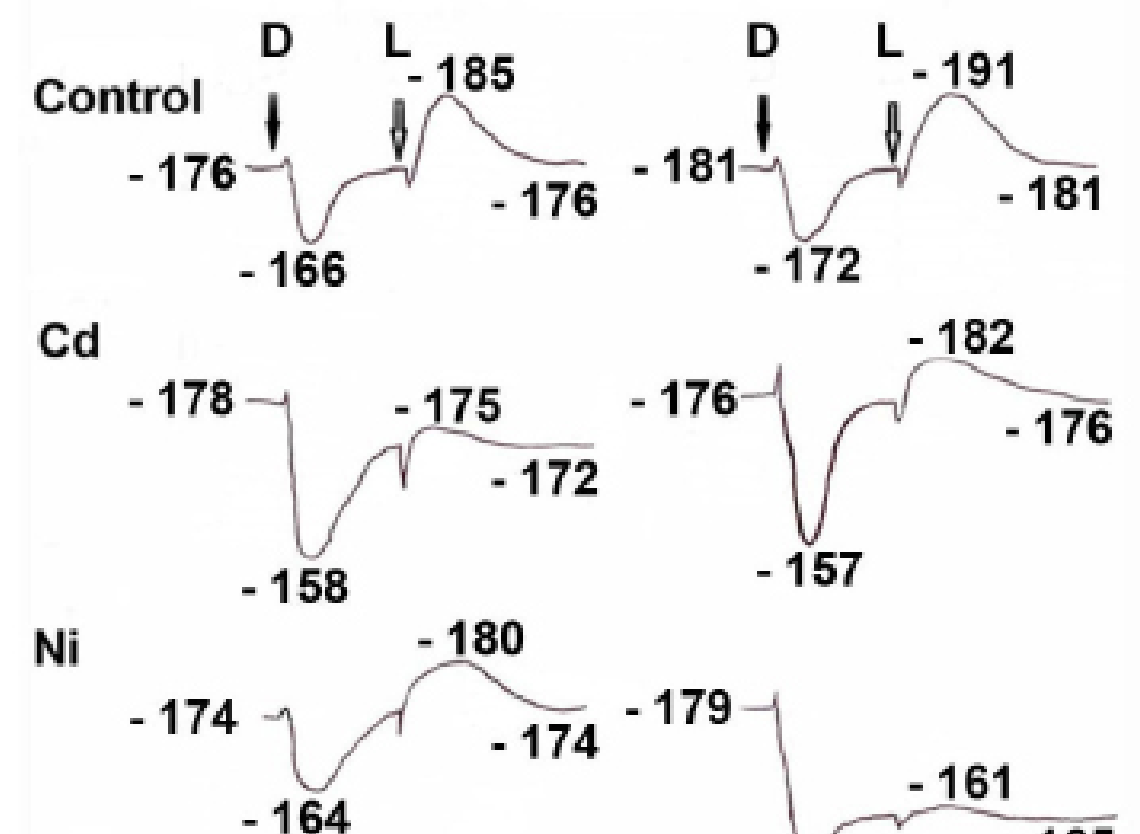

$\mathrm{Cd}+\mathrm{Ni}$
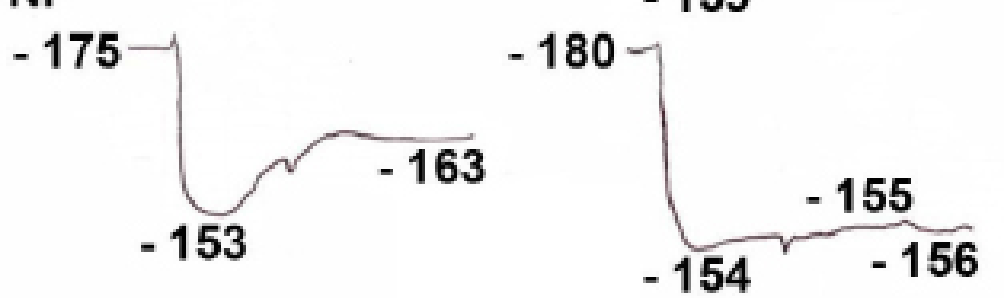

Figure 2. Transient $E_{\mathrm{M}}$ changes in leaf mesophyll cell (representative traces of five to seven measurements) caused by transition from light to dark (D) and dark to light (L) in control and after $72 \mathrm{~h}$ exposure to $2 \mu \mathrm{mol}^{\mathrm{M}} \mathrm{L} \mathrm{Cd}^{2+}, 2$ $\mu \mathrm{mol} / \mathrm{L} \mathrm{Ni}^{2+}$, or $2 \mu \mathrm{mol} / \mathrm{L} \mathrm{Cd}^{2+}+2 \mu \mathrm{mol} / \mathrm{L} \mathrm{Ni}^{2+}$ in the leaf media. 


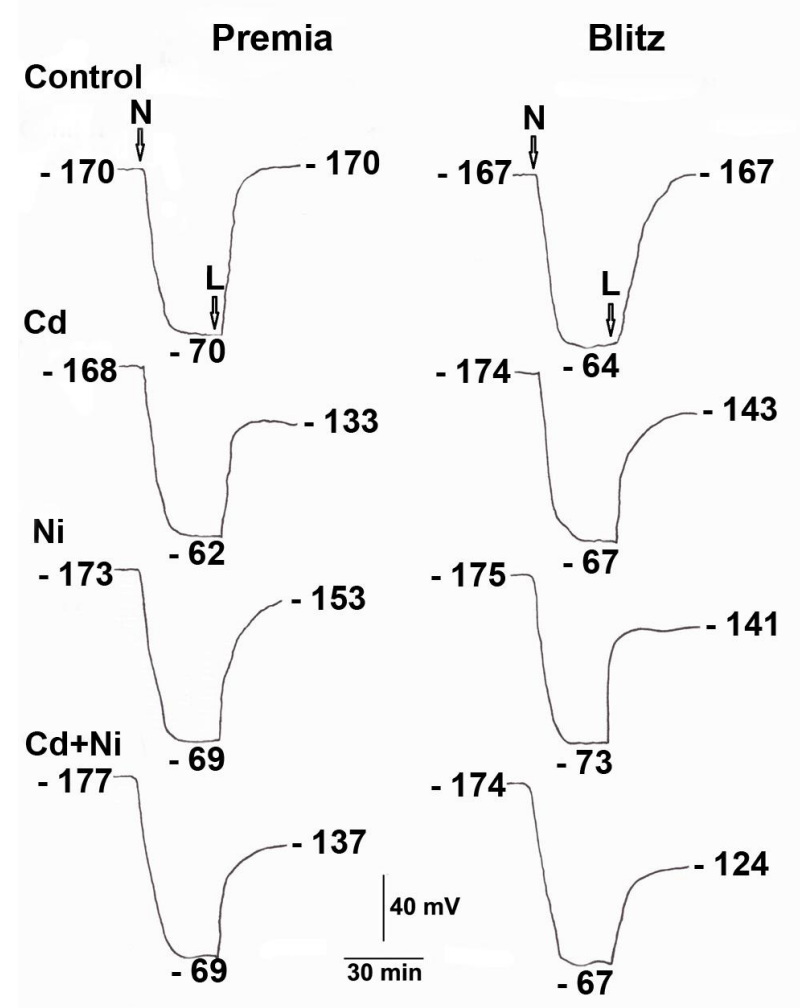

Figure 3. Responses of maize leaf mesophyll cell $E_{\mathrm{M}}$ (representative traces of four to nine measurements) undergoing anoxia $(\mathrm{N})$ in dark, and after switching light on (L) in control and after $72 \mathrm{~h}$ exposure to $2 \mu \mathrm{mol} / \mathrm{L}$ $\mathrm{Cd}^{2+}, 2 \mu \mathrm{mol} / \mathrm{L} \mathrm{Ni}^{2+}$, or $2 \mu \mathrm{mol} / \mathrm{L} \mathrm{Cd}^{2+}+2 \mu \mathrm{mol} / \mathrm{L} \mathrm{Ni}^{2+}$ in the leaf media.

ability with a subsequent disturbance of the cellular ionic balance, recorded as an increased $\mathrm{K}^{+}$efflux or conductivity HM-treated plants (Wu et al. 2003; Sanz et al. 2009; Fiala et al. 2015). The presence of $2 \mu \mathrm{mol} / \mathrm{L}$ concentrations of the HMs in the experimental solutions did not enhance $\mathrm{K}^{+}$leakage from the Premia leaf segments expressed as percent of total content in the surrounding media within $72 \mathrm{~h}$. Such a response was significant only in the cultivar Blitz after the treatment with $\mathrm{Cd}+\mathrm{Ni}$ (Table 2 ) and it was reported to be associated with metal-induced lipid peroxidation in rice (Gajewska et al. 2012). The complete absence of $\mathrm{K}^{+}$leakage from the Premia leaves and from Blitz leaves treated with $\mathrm{Cd}$ and Ni confirms that the Premia leaf cells were able to cope with the elevated metal concentrations better in comparison to Blitz. Our results differ from those on roots of the same maize cultivars treated with high concentration of $\mathrm{Cd}, \mathrm{Ni}$ and $\mathrm{Cd}+\mathrm{Ni}$ (Fi- ala et al. 2015), where the membrane permeability increased in all metal treatments. These differences can be explained by using high concentrations of the metals $(10 \mu \mathrm{M}$ and $100 \mu \mathrm{M})$ for treatments of the roots and by different sensitivity of root cells to the studied metals in comparison with the sensitivity of mesophyl leaf cells.

On the other hand, measurement of TBARS, a common product of lipid peroxidation, is regarded as a reliable method for evaluating the degree of lipoperoxidation, which may be caused by metal-induced changes in the composition of the membrane lipids and the saturation of fatty acids (Gajewska et al. 2012). In our experiments, the levels of TBARS in the leaves were not markedly changed, with the exception of the seedlings of maize cultivar Blitz subjected to combined $\mathrm{Cd}$ and $\mathrm{Ni}$ stress. In this variant, the contents of TBARS exceeded the control significantly (Table 2). This is in accordance with simultaneous increase in membrane permeability and TBARS content in wheat seedlings treated with Ni (Gajewska et al. 2012). The difference between the cultivars was probably due to differences in the ratio of unsaturated and saturated fatty acids as has previously been shown in Silene plants tolerant and susceptible to copper (DeVos et al. 1993).

In addition to the above-mentioned direct effects of $\mathrm{Cd}$ and $\mathrm{Ni}$ on the PM integrity, these metals as divalent cations may compete with other essential mineral nutrients in their transport across membranes. Our results on the decrease of $\mathrm{K}^{+}$content in maize leaves also confirmed such competition. In the seedlings grown with roots exposed to $\mathrm{Cd}, \mathrm{Ni}$, and $\mathrm{Cd}+\mathrm{Ni}$ for $72 \mathrm{~h}$, the total $\mathrm{K}^{+}$content decreased in the leaf tissues in both cultivars (Table 2). Similar results were found by Gabbrielli et al. (1999) who showed that in shoots and roots of pea plants, the toxic concentrations of $\mathrm{Ni}$ lowered $\mathrm{K}^{+}$content but did not cause an increase in $\mathrm{K}^{+}$efflux. The authors suggest that the effect could be due to a decrease in $\mathrm{K}^{+}$uptake rather than by direct effect on membrane permeability. Moreover, Rubio et al. (1994) showed that $\mathrm{Cd}$ and $\mathrm{Ni}$ treatments also induced a decrease in $\mathrm{K}^{+}, \mathrm{Ca}^{2+}$ and $\mathrm{Mg}^{2+}$ content in rice plants, particularly in the shoots, indicating that $\mathrm{Cd}$ and $\mathrm{Ni}$ interfered not only with nutrient uptake but also with nutrient distribution into the different plant parts. In our set of experiments, we found an antagonism of metal 
ions in relation to $\mathrm{K}^{+}$content, which was higher under joint $\mathrm{Cd}+\mathrm{Ni}$ than under individual metal exposure. This resembles the competitive interactions restricting the entry of HMs into the Elodea leaf cells (Maleva et al. 2012).

\section{AsA and DHA}

In plants, antioxidative responses are largely based on the use and recycling of both AsA and
GSH, complemented by superoxide dismutase and catalase. Both AsA/DHA and GSH/GSSG are major cellular redox buffers. Changes in the ratios of the reduced and oxidised forms reflect cellular toxicity and have been associated with redox signalling (reviewed by Anjum et al. 2014). AsA is able to directly neutralise oxygen radicals and recover tocopherol, thus protecting the membranes. Ascorbate also



Figure 4. Contents of AsA and its oxidised forms (DHA) in the leaf tissues of maize cultivars Premia and Blitz in control and after $72 \mathrm{~h}$ exposure to $2 \mu \mathrm{mol} / \mathrm{L} \mathrm{Cd}^{2+}, 2 \mu \mathrm{mol} / \mathrm{L} \mathrm{Ni}^{2+}$, or $2 \mu \mathrm{mol} / \mathrm{L} \mathrm{Cd}^{2+}+2 \mu \mathrm{mol} / \mathrm{L} \mathrm{Ni}^{2+}$ in the root media. (Means $\pm \mathrm{SD}$; the same letters indicate no statistically significant differences at $P<0.05$ ).

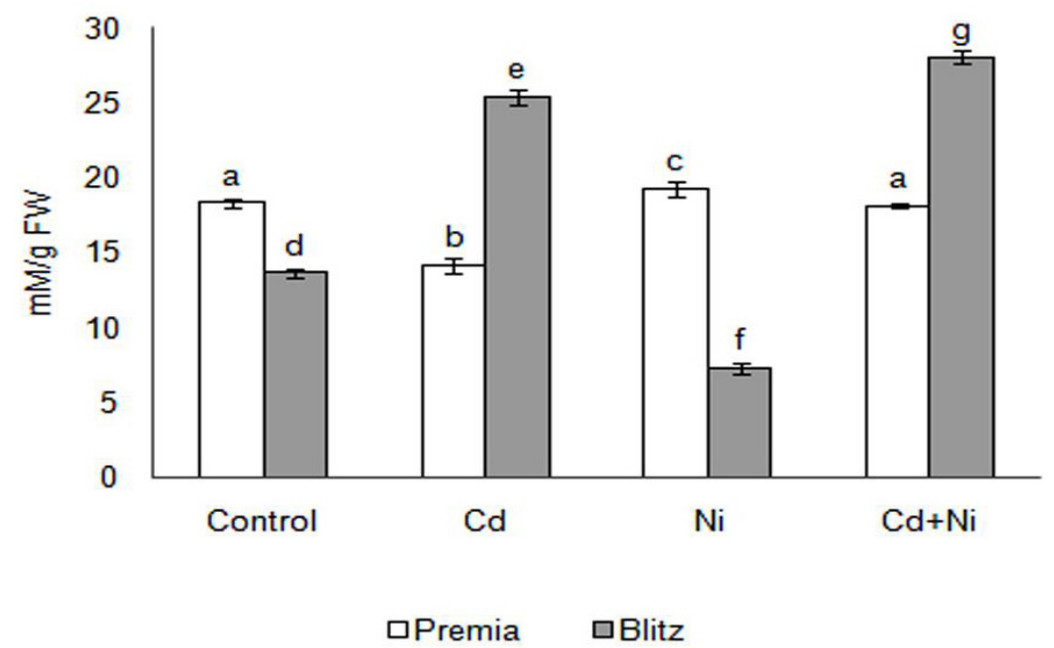

Figure 5. Contents of total glutathione (GSH) in the leaf tissues of maize cultivars Premia and Blitz in control and after $72 \mathrm{~h}$ exposure to $2 \mu \mathrm{mol} / \mathrm{L} \mathrm{Cd}^{2+}, 2 \mu \mathrm{mol} / \mathrm{L} \mathrm{Ni}^{2+}$, or $2 \mu \mathrm{mol} / \mathrm{L} \mathrm{Cd}^{2+}+2 \mu \mathrm{mol} / \mathrm{L} \mathrm{Ni}^{2+}$ in the root media. (Means $\pm \mathrm{SD}$; the same letters indicate no statistically significant differences at $P<0.05$ ). 
functions as co-substrate of plant oxidases, such as ascorbate peroxidase system, which produces dehydroascorbic acid. HMs induce changes in the AsA/ DHA ratio, depending on plant species and metal stress conditions. Therefore, to understand the contribution of the non-enzymatic antioxidants in response of maize seedlings to $\mathrm{Cd}$ and $\mathrm{Ni}$ toxicity, we examined leaf concentrations of AsA, DHA and GSH.

In the leaves of Premia seedlings exposed to cadmium and nickel single or combined, the amounts of AsA decreased and DHA increased significantly (Figure 4). One of the causes might be neutralising free radicals by oxidation of AsA. Decreasing amount of AsA caused by Cd stress was noted in leaves of Pisum sativum (Romero-Puertas et al. 2007) and Oryza sativa (Chao et al. 2010). In the leaves of cultivar Blitz, the AsA content increased only under the exposure to single nickel (Figure 4). The single metal impact might cause activation of de novo AsA synthesis necessary for the removal of free radical reactions in the leaves. As a result of these processes, the amount of oxidised forms of ascorbate increased (Figure 4). With the combined action of $\mathrm{Cd}+\mathrm{Ni}$ in both variants, there is a tendency of decreasing AsA amount while increasing that of its oxidised forms. This, in our opinion, can be explained by a decrease of AsA pool resulting from the intensification of its utilisation in hindering lipid oxidation by free radicals. Our results are in agreement with the findings of other authors, e.g. decreasing amount of AsA in the roots of Kandelia candel and Bruguiera gymnorrhiza treated with heavy metal mixture $\left(\mathrm{Cd}^{2+}, \mathrm{Pb}^{2+}\right.$ and $\left.\mathrm{Hg}^{2+}\right)$ in the concentration of $1.5 \mathrm{mg} / \mathrm{L}$ (Huang et al. 2010). The cultivar Blitz seems to be more sensitive to $\mathrm{Ni}$, whereas the hybrid Premia to Cd ions. The results show that AsA in cultivar Blitz may play a more important role in the fight against heavy metal-induced oxidative damage than it does in the cultivar Premia.

\section{$G S H$}

GSH is not only a central compound in sulphur metabolism but also a major component of the cellular antioxidative defence system against HM toxicity. GSH acts as disulphide reductant to protect thiol $(-\mathrm{SH})$ groups on enzymes, regenerates AsA and reacts with singlet oxygen and hydroxyl radi- cals. A number of reports are available regarding the depletion of GSH pool in Cd- and Ni-exposed plants (Sharma \& Dhiman 2013).

The concentration of GSH in the leaf tissues varied in dependence of maize cultivar as well as of metal treatment (Figure 5). In control conditions, the concentration of GSH was significantly higher in the leaf tissues of Premia than of Blitz. Differences in GSH content were found in other species, e.g. the leaves and roots of Arabidopsis thaliana plants exposed to Cd (Jozefczak et al. 2015), in which the wild type responded with statistically higher content of GSH in comparison to the GSH-deficient mutants. Compared to control, the $\mathrm{Cd}$ treatment decreased GSH content in Premia and increased in Blitz. The Ni treatment had an opposite effect, resulting in increase of the GSH content in Premia and decrease in Blitz. The joint $\mathrm{Cd}+\mathrm{Ni}$ treatment had no effect on GSH level in Premia but increased it in Blitz (Figure 5). According to these data, the cultivar Blitz seemed to respond more sensitively to $\mathrm{Ni}$ ions. In this case, there were no changes of GSH content in Premia synthesis and the pool of another antioxidant available in cells was used. The increase in GSH concentration induced by $\mathrm{Cd}$ in Blitz could be caused by active functioning of enzymatic system of its reutilisation. Based on the changes in GSH content, the cultivar Premia reveals a higher sensitivity to cadmium as the concentration of GSH decreased in Cd-treated or remained unchanged in all other variants. Most likely, in Premia, the obtained data can testify a primary functioning of other antioxidant systems (in particular ascorbate-dependent) for neutralisation of the negative influence of the metals. Similar results were found in rice seedlings tolerant and sensitive to $\mathrm{Cd}$, in which the content of GSH decreased in the leaves of Cd-sensitive cultivar but not in the Cd-tolerant cultivar (Chao et al. 2011), or in the roots of the same maize cultivars (Artiushenko et al. 2014).

\section{CONCLUSIONS}

Our results suggest that in maize plants subjected to $2 \mu \mathrm{mol} / \mathrm{L} \mathrm{Cd}^{2+}, \mathrm{Ni}^{2+}$ or both metals together, antioxidants (ASA, DHA and GSH) were activated, and different responses between cultivars and 
metals were also observed. Concerning the metals, the interaction of $\mathrm{Cd}$ and $\mathrm{Ni}$ revealed antagonistic relations in their accumulation in the leaf tissues, while synergic effect of the metals was manifested in greater dark-induced depolarisation and lightinduced repolarisation after $\mathrm{Cd}+\mathrm{Ni}$ treatment than after the single ions. Concerning the cultivars, both of them revealed the tendency of accumulating more $\mathrm{Ni}$ than $\mathrm{Cd}$ while they differed in the metal-induced changes of antioxidant contents.

Generally, the data obtained from both cultivars appear to support the concept that controlling the capacity of antioxidants in different maize cultivars should be an integral part of the evaluation and quantification of the effects of $\mathrm{Cd}^{2+}$ and $\mathrm{Ni}^{2+}$ stress on plants. Moreover, it is supposed that the observed decrease in $\mathrm{K}^{+}$uptake but not direct effect on membrane permeability and $E_{\mathrm{M}}$ in HM-treated plants can be considered as stress symptoms. On the other hand, the addition of the second metal to the root medium alleviated the detrimental action of individual ions owing to the enhanced $\mathrm{K}^{+}$content.

Acknowledgements. This work was supported by Grant Agency VEGA, Project No 2/0023/13, and by the inter-academic agreement between SAS and UAN, Project No. 17.

\section{REFERENCES}

AHMAD, M.S. - ASHRAF, M. 2011. Essential roles and hazardous effects of nickel in plants. In Reviews Environmental Contamination and Toxicology, vol. 214, pp. 125-167.

ALEGRIA, A. - BARBERÁ, R. - BOLUDA, R. - ERRECALDE, F. - FARRÉ, R. LAGARDA, M.J. 1991. Environmental cadmium, lead and nickel contamination: possible relationship between soil and vegetable content. In Fresenius Journal of Analytical Chemistry, vol. 339, no. 9, pp. 654-657.

ANGELOVA, V. - IVANOVA, R. - IVANOV, K. 2004. Heavy metal accumulation and distribution in oil crops. In Communications in Soil Science and Plant Analysis, vol. 35, no. 17-18, pp. 2551-2566.

ANJUM, N.A. - AREF, I.M. - DUARTE, A.C. - PEREIRA, E. - AHMAD, I. - IQBAL, M. 2014. Glutathione and proline can coordinately make plants withstand the joint attack of metal(loid) and salinity stresses. In Frontiers in Plant Sciences, vol. 5, 662, online at http://dx.doi. org/10.3389/fpls.2014.00662, PMC4240066

ARTIUSHENKO, T. - SYSHCHYKOV, D. - GRYSHKO, V. - ČIAMPOROVÁ, M. -FIALA, R. - REPKA, V. - PAV-
LOVKIN, J. 2014. Metal uptake, antioxidant status and membrane potential in maize roots exposed to cadmium and nickel. In Biologia, vol. 69, no. 9, pp. 1142-1147.

BARTOLI, F. - COINCHELIN, D. - ROBIN, C. - ECHEVARRIA, G. 2012. Impact of active transport and transpiration on nickel and cadmium accumulation in the leaves of the Ni-hyperaccumulator Leptoplax emarginata: a biophysical approach. In Plant and Soil, vol. 350, no. 1, pp. 99-115.

BEUTLER, E. - DURAN, O. - KELLY, B.U. 1963. The definition of glutathione in blood. In Journal of Laboratory and Clinical Medicine, vol. 61, no. 5, pp. 882-886.

BORZOU, A. - AZIZINEZHAD, F.J. 2012. Investigation of lettuce pollution with cadmium and lead in Varamin region in Iran. In Research Journal of Pharmaceutical, Biological and Chemical Sciences, vol. 3, no. 4, pp. 317-324.

CHAO, Y.Y. - HONG, C.Y. - KAO, C.H. 2010. The decline in ascorbic acid content is associated with cadmium toxicity of rice seedlings. In Plant Physiology and Biochemistry, vol. 48, no. 5, pp. 374-381.

CHAO, Y.Y. - HONG, C.Y. - CHEN, C.Y. - KAO, C.H. 2011. The importance of glutathione in defence against cadmium-induced toxicity of rice seedlings. In Crop, Environment and Bioinformatics, vol. 8, no. 3, pp. 217-228.

CHOPRA, A.K. - PATHAK, C. - PRASAD, G. 2009. Scenario of heavy metal contamination in agricultural soil and its management. In Journal of Applied and Natural Science, vol. 1, no. 1, pp. 99-108.

DE VOS, C.H.R. - BOOKUM, W.M.T. - VOOIJS, R. SCHAT, H. - DE KOK, L.J. 1993. Effect of copper on fatty acid composition and peroxidation of lipids in the roots of copper tolerant and sensitive Silene cucubalus. In Plant Physiology and Biochemistry, vol. 31, no. 2, pp. 151-158.

DUAN, Y.P. - YUAN, S. - TUB, S.H. - FENG, W.Q. - XUC, F. - ZHANG, Z.W. - CHEN, Y.E. WANG, X. - SHANG, J. - LIN, H.H. 2010. Effects of cadmium stress on alternative oxidase and photosystem II in three wheat cultivars. In Zeitschrift für Naturforschung $C$, vol. 65, no. 1-2, pp. 87-94.

FIALA, R. - REPKA, V. - ČIAMPOROVÁ, M. - MARTINKA, M. - PAVLOVKIN, J. 2015. The effect of cadmium-nickel interactions on superoxide production, cell viability and membrane potential $\left(\mathrm{E}_{\mathrm{M}}\right)$ in roots of two maize cultivars. In Acta Biologica Hungarica, vol. 66, no. 2 , pp. 192-204.

GABBRIELLI, R. - PANDOLFINI, T. - ESPEN, L. PALANDRI, M.R. 1999. Growth, peroxidase activity and cytological modifications in Pisum sativum seedlings exposed to $\mathrm{Ni}^{2+}$ toxicity. In Journal of Plant Physiology, vol. 155 , no. $4-5$, pp. 639-645.

GAJEWSKA, E. - BERNAT, P. - DŁUGOŃSKI, J. SKŁODOWSKA, M. 2012. Effect of nickel on membrane integrity, lipid peroxidation and fatty acid composition in wheat seedlings. In Journal of Agronomy and Crop Science, vol. 198, no. 4, pp. 286-294.

GHASEMI, F. - HEIDARI, R. - JAMEII, R. - PURAKBAR, L. 2012. Effects of $\mathrm{Ni}^{2+}$ toxicity on Hill reaction and membrane functionality in maize. In Journal of Stress Physiology and Biochemistry, vol. 8, no. 4, pp. 55-61. 
GONZALEZ-MENDOZA, D. - QUIROZ-MORENOB, A. ESCOBEDO, R. - MEDRANOC, G. - GRIMALDO-JUAREZA, O. - ZAPATA-PEREZ, O. 2009. Cell viability and leakage of electrolytes in Avicennia germinans exposed to heavy metals. In Zeitschrift für Naturforschung $C$, vol. 64, no. 5-6, pp. 391-394.

GRYSHKO, V.N. - SYSHCHYKOV, D.V. 2002. Method for determination of glutathione reduced form in plant vegetative organs. In Ukraine Biochemistry Journal, vol. 74, no. 2, pp. 123-124.

HODGES, D.M. - DELONG, J.M. - FORNEY, C.F. PRANGE, R.K. 1999. Improving the thiobarbituric acid-reactive-substances assay for estimating lipid peroxidation in plant tissues containing anthocyanin and other interfering compounds. In Planta, vol. 207, no. 4, pp. 604-611.

HUANG, GY. - WANG, YS. - SUN, CC. - DONG, JD. SUN, ZX. 2010. The effect of multiple heavy metals on ascorbate, glutathione and related enzymes in two mangrove plant seedlings (Kandelia candel and Bruguiera gymnorrhiza). In Oceanological and Hydrobiological Studies, vol. 39, no. 1, pp. 11-25.

JOZEFCZAK, M. - BOHLER, S. - SCHAT, H. - HOREMANS, N. - GUISEZ, Y. - REMANS, T. - VANGRONSVELD, J. - CUYPERS, A. 2015. Both the concentration and redox state of glutathione and ascorbate influence the sensitivity of arabidopsis to cadmium. In Annals of Bota$n y$, on line at www.aob.oxfordjournals.org, doi:10.1093/ aob/mcv075.

KAMPFENKEL, K. - VAN MONTAGU, M. - INZE, D. 1995. Extraction and determination of ascorbate and dehydroascorbate from plant tissue. In Analytical Biochemistry, vol. 225, no. 1, pp. 165-167.

KURTYKA, R. - BURDACH, Z. - KARCZ, W. 2011. Effect of cadmium and lead on the membrane potential and photoelectric reaction of Nitellopsis obtusa cells. In General Physiology and Biophysics, vol. 30, no. 1, pp. 52-58.

MAXIMOVIĆ, I. - KASTORI, R. - KRISTIĆ, L. - LUKOVIČ, J. 2007. Steady presence of cadmium and nickel affects root anatomy, accumulation and distribution of essential ions in maize seedlings. In Biologia Plantarum, vol. 51, no. 3, pp. 589-92.

MALEVA, M.G. - NEKRASOVA, G.F. - BORISOVA, G.G. - CHUKINA, N.V. - USHAKOVA, O.S. 2012. Effect of heavy metals on photosynthetic apparatus and antioxidant status of Elodea. In Russian Journal of Plant Physiology, vol. 59, no. 2, pp. 216-224.

NAKAZAWA, R. - OZAWA, T. - NAITO, T. - KAMEDA, Y. - TAKENAGA, H. 2001. Interactions between cadmium and nickel in phytochelatin biosynthesis and detoxification of the two metals in suspension-cultured tobacco cells. In Biologia Plantarum, vol. 44, no. 4, pp. $627-630$.

PANDEY, N. - PATHAK, G.C. - PANDEY, D.K. - PANDEY, R. 2009. Heavy metals, $\mathrm{Co}, \mathrm{Ni}, \mathrm{Cu}, \mathrm{Zn}$ and $\mathrm{Cd}$, produce oxidative damage and evoke differential antioxidant responses in spinach. Brazilian. In Journal of Plant Physiology, vol. 21, no. 2, pp. 103-11.

PAVLOVKIN, J. - NOVACKY, A. - ULLRICH-EBERIUS, C.I. 1986. Membrane potential changes during bacteria-induced hypersensitive reaction. In Physiological and Molecular Plant Pathology, vol. 28, no. 1, pp. 125-135.
PAZURKIEWICZ-KOCOT, K. - PIETRUSZKA, M. 2000. The effect of lead on the photoelectric reaction of Zea mays L. plants. In Journal of Photochemistry and Photobiology, vol. 57, no. 2-3, pp. 119-122.

PINTO, J.C. - CHAVES, C.A. - PEREZ, J.R.O. - OLIVEIRA, A.I.G. - DE ROCHA, G.P. 1999. Nutritive value of sudan grass, millet, teosinte and corn silages. Intake and apparent digestibility. In Ciencia e Agrotecnologia, vol. 23, no. 4, pp. 981-987.

ROMERO-PUERTAS, M.C. - CORPAS, F.J. - RODRIGUEZ-SERRANO, M. - GOMEZ, M. - DEL RÍO, L.A. - SANDALIO, L.M. 2007. Differential expression and regulation of antioxidative enzymes by $\mathrm{Cd}$ in pea plants. In Journal of Plant Physiology, vol. 164, no. 10, pp. 1346-1357.

ROS, R. - MORALES, A. - SEGURA, J. - PICAZO, I. 1992. In vivo and in vitro effects of nickel and cadmium on the plasmalemma ATPase from rice (Oryza sativa L.) shoots and roots. In Plant Sciences, vol. 83, no. 1, pp. 1-6.

RUBIO, M.I. - ESCRIG, I. - MARTÍNEZ-CORTINA, C.F. - LÓPEZ-BENET, J. - SANZ, A. 1994. Cadmium and nickel accumulation in rice plants. Effects on mineral nutrition and possible interactions of abscisic and gibberellic acids. In Plant Growth Regulation, vol. 14, no. 2, pp. 151-157.

SANZ, A. - LLAMAS, A. - ULLRICH, C.I. 2009. Distinctive phytotoxic effects of $\mathrm{Cd}$ and $\mathrm{Ni}$ on membrane functionality. In Plant Signal Behavior, vol. 4, no. 10, pp. 980-982.

SEREGIN, I.V. - KOZHEVNIKOVA, A.D. 2008. Roles of root and shoot tissues in transport and accumulation of cadmium, lead, nickel, and strontium. In Russian Journal of Plant Physiology, vol. 55, no. 1, pp. 1-22.

SHABALA, S. - NEWMAN, I. 1999. Light-induced changes in hydrogen, calcium, potassium, and chloride ion fluxes and concentrations from mesophyll and epidermal tissues of bean leaves. Understanding the ionic basis of light-induced bioelectrogenesis. In Plant Physiology, vol. 119, no. 3, pp. 1115-1124.

SHARMA, R.K. - AGRAWAL, M. - MARSHALL, F. 2007. Heavy metal contamination of soil and vegetables in suburban areas of Varanasi, India. In Ecotoxicology and Environmental Safety, vol. 66, no. 2, pp. 258-266.

SHARMA, A. - DHIMAN, A. 2013. Nickel and cadmium toxicity in plants. In Journal of Pharmaceutical and Scientific Innovation, vol. 2, no. 2, pp. 20-24.

TRAN, T.A. - POPOVA, L.P. 2013. Functions and toxicity of cadmium in plants: recent advances and future prospects. In Turkish Journal of Botany, vol. 37, no. 1, pp. 1-13.

ULLRICH-EBERIUS, C.I. - NOVACKY, A. - BALL, E. 1983. Effects of cyanide in dark and light on the membrane potential and ATP level of young and mature green tissues of higher plants. In Plant Physiology, vol. 72, no. 1, pp. 7-15.

WU, F. - GUOPING, Z. - DOMINY, P. 2003. Four barley genotypes respond differently to cadmium: lipid peroxidation and activities of antioxidant capacity. In Environmental and Experimental Botany, vol. 50, no. 1, pp. $67-78$.

Received: September 27, 2016 